\title{
Dryer performance - Reducing energy consumption, improving the product and sharing information
}

Whaley, M. ${ }^{\mathbf{a}^{*}}$; Poandl, F. ${ }^{\mathbf{b}}$

a Principle Process Engineer, Buhler Aeroglide

b Associate Chief Engineer, Buhler Aeroglide.

*E-mail of the corresponding author: michael.whaley@buhlergroup.com

\begin{abstract}
The evaporation of water is a major energy consumer around the world where the evaporation of water from agricultural products, natural resources, processed foods and feeds, and petrochemical products is required for long term storage, subsequent processing or other desired attributes.

The control of product attributes associated with drying can also be challenging in terms of measurement and modelling which may lead to inefficiencies in the operation of a dryer.

This discussion below will address solutions to improve the thermal efficiency of dryers and to control the critical properties of the product being dried. In addition, the benefits of haring information between the dryer supplier and the dryer operator will be discussed through the use of the Industrial Internet of Thing
\end{abstract}

Keywords: heat recover; design; control. 


\section{Heat Recovery for Conveyor Dryers}

In a well-balanced conveyor dryer, the energy associated with evaporation of water represents approximately $65 \%$ of the thermal energy input. The remaining energy is consumed by the hot exhaust air stream, the temperature increase in the product, and ambient losses to the environment. Much of this energy may be recovered by cooling the product after the drying step and using this air within the dryer, recovering the sensible and latent heat in the exhaust to pre-heat make-air, recovering energy for steam condensate, and improving the insulation of the dryer construction.

In order to reduce operating costs, energy conservation and heat recovery should be paramount to the configuration of any unit operation, specifically thermal drying. Numerous drying technologies benefit from energy recovery; however, the platform of this study focuses on reducing utility consumption in regards to conveyor drying. Gel drying applications are used as examples for recovering energy and recycling heat within the dryer. Drying the gel yields effluent streams with sufficient internal energy to justify modifying the process design of the dryer for heat recovery. Opportunities for heat recovery include cascading airflow, heat recovery from the exhaust air, and condensateflashing to maximize the energy from the steam supply.

Drying wet material requires a large amount of energy/mass transfer to obtain the desired final moisture content of the product. The physical properties of the gel have an inlet moisture typically around $50-60 \%$ wwb, while the desired outlet moisture range is $3-5 \%$ wwb. Depending upon the nature of the gel, the product is first tested in a laboratory dryer to establish optimal drying conditions for air temperature, velocity, and bed depth. Many cellulous or protein derived gel polymers are sensitive to air temperature, unlike refined gel polymers from petroleum based reactions. The latter is considered for the purpose of this analysis. Dryer components (fans, heat source, etc.) are designed for high process air temperatures ( $\mathrm{T}$ range $165-180^{\circ} \mathrm{C}$ ) and flow rates through the stacked bed of product ( $\mathrm{V}$ range of 1.6-2 m/s) in order to facilitate a high rate of evaporation. A typical gel conveyor dryer configuration can be seen in Figure 1.

Buhler Aeroglide has a proprietary heat and mass balance spreadsheet, in which the process is broken down to identify areas where energy can either be reduced or reused. Figure 2 shows an approximate energy consumption profile for a conveyor dryer, without heat recovery, producing dried gel at five tons per hour. As seen in the bar chart, water evaporation requires the most amount of energy due to the phase change. The second largest contribution to the thermal load is from heating a supply of cool dry make-up air in exchange for hot wet exhaust air. For this example, the most beneficial savings can be achieved by recovering the thermal energy used to evaporate the water and heat the make-up air. These dryers also have a cooling zone; therefore, heat from the product can be recovered by 
recycling air from the cooling exhaust. Improving the dryer design to limit ambient heat losses will also improve the energy efficiency.

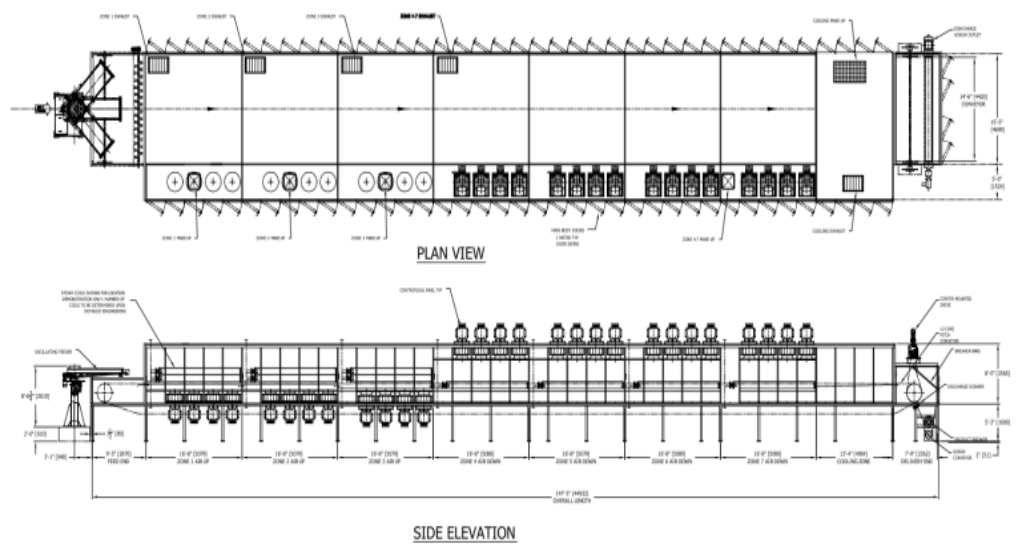

Figure 1 - Gel dryer configuration

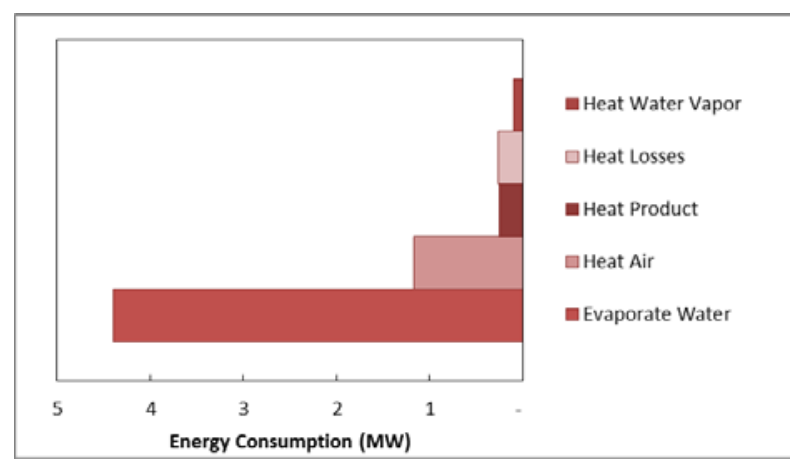

Figure 2 - Gel energy breakdown

For dryers without heat recovery, over six mega-watts of energy is required to produce five tons per hour of dried gel. These values do not include the electrical load to operate the mechanical equipment (conveyors, fans, etc.). Gel drying application are ideal for heat recovery because the production and evaporation rates are substantial for systems producing more than four tons per hour. Thermally processing gel incurs high energy consumption and utility costs. As mentioned previously, the gel enters the dryer with an average moisture content between 50-60\% wwb and exits at 3-5\%. Operating expenses, for a dryer demanding $6 \mathrm{MW}$ of thermal energy for evaporation, are considerable.

The operating costs associated with the dryer can be reduced based on the energy recovery options. However, there were parameters that were constant throughout the simulations. The quality of the air entering the dryer was defined at ambient conditions ( $\mathrm{TDB}=20^{\circ} \mathrm{C}$ ) and sea level. Also, the general dryer configuration and process parameters were standardized while 
modeling the energy options. The defined process operating conditions and assumed rheological properties are in noted in Table 1. As mentioned, the overall configuration of the dryer in regards to airflow direction, drying/cooling area, and general arrangement were consistent. In terms of design, the conveyor dryer is a single pass, single plenum machine. Each simulation had six drying zones with an extended cooling zone. The direction of airflow in the first three zones were upflow, proceeded by downflow air in the later sections of the dryer.

Table 1 - Dryer process parameters

\begin{tabular}{ll}
\hline Parameter & Value \\
\hline Production Rate $(\mathrm{kg} / \mathrm{hr})$ & 5.000 \\
Inlet Moisture $(\% \mathrm{wwb})$ & 60 \\
Outlet Moisture $(\% \mathrm{wwb})$ & 5 \\
Wet Density $\left(\mathrm{kg} / \mathrm{m}^{3}\right)$ & 460 \\
Product Depth $(\mathrm{mm})$ & 100 \\
Retention Time $(\mathrm{min})$ & 30 \\
Air Temperature $\left({ }^{\circ} \mathrm{C}\right)$ & 160 \\
Air Velocity $(\mathrm{m} / \mathrm{s})$ & 1,65 \\
\hline
\end{tabular}

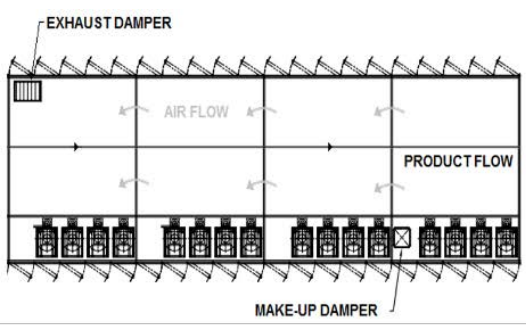

(a)

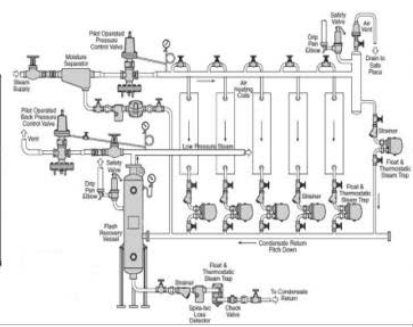

(b)

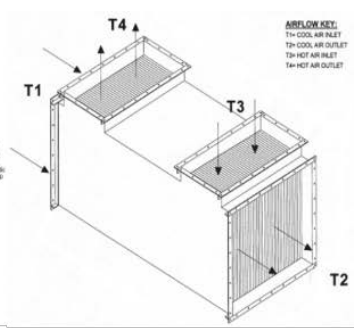

(c)

Figure 3 - (a) Buhler aeroglide cascading air flow, (b) Flash steam system (c) Air to heat exchanger

The simulations share many design features in common; however, the energy recovery features were unique to each. This study focused primarily on cascading airflow, air-to-air heat recovery from exhaust to make-up, and condensate flashing to preheat make-up air. Figures 3a, 3b (Spirax Sarco Inc., "Design of Fluid Systems - Hook-Ups” 2012. pg. 97), and 3c (Munters Corporation, “Counterflow Plate Type Air-to-Air Heat Exchangers” 2013) provide illustrations of the equipment.

\subsection{Base Design}

The first scenario that was modeled had no heat recovery in addition to the recirculated air. The results of the energy and mass balance for Case 1 can be seen in Table 2. The dryer's 
exhaust and makeup air flow were set to provide absolute humidity levels in the exhaust of $0.15 \mathrm{~kg} 2 \mathrm{O} / \mathrm{kg}_{\mathrm{DA}}$.

Table 2 - Case 1: Results

\begin{tabular}{ll}
\hline Dryer Performance & Value \\
\hline Energy Usage $(\mathrm{kW})$ & 6.045 \\
Steam Usage $(\mathrm{kg} / \mathrm{hr})$ & 11.442 \\
Spec. Energy Consumption $\left(\mathrm{kJ} / \mathrm{kg}_{\text {Evp }}\right)$ & 3.166 \\
Spec. Steam Consumption $\left(\mathrm{kg} \mathrm{kteam}_{\mathrm{kgv}}\right)$ & 1,66 \\
Spec. Moisture Extraction Rate $\left(\mathrm{kg} \mathrm{Evp}_{\text {EvWh}} / \mathrm{kW}\right)$ & 1,14 \\
\hline
\end{tabular}

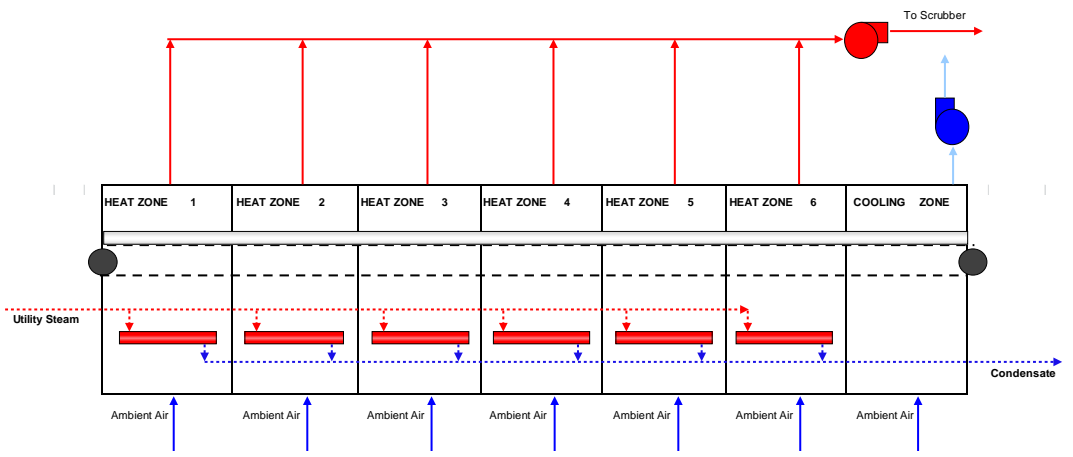

(BOHLER

Figure 4 - Case 1: Process flow diagram

Case 1 represents the most energy intensive and least cost effective option from an operating perspective. This scenario is a reference point for the following simulations and it is identical to the energy breakdown shown in Figure 2. Table 2 shows the specific energy and steam consumption along with the specific moisture extraction rate. These values are frequently used to compare similar drying applications but at varying sizes and production rates. They will be used as a baseline for the following energy Cases.

\subsection{Cooler exhaust air used as dryer make-up air}

The second scenario focused on heat recovery from the cooling exhaust. In this design, the air being exhausted from the cooling section was ducted to the makeup air dampers entering each heat zone. The makeup air to each zone was no longer at ambient conditions; rather, it was preheated $\left(\mathrm{T}_{\mathrm{DB}}=30^{\circ} \mathrm{C}\right)$. The cooling exhaust air flow rate was set based on the required makeup air mass flow rate. Similarly to Case 1, it was assumed that the quality of the air entering the cooler was at ambient conditions $\left(\mathrm{T}_{\mathrm{DB}}=20^{\circ} \mathrm{C}\right)$ and sea level. 
Table 3 shows the calculated energy and mass balance results for Case 2. When compared to Case 1 , there was a $2 \%$ savings in energy usage. As expected, the specific energy and steam consumption are less because the same about water was evaporated using less energy. Similarly, the specific moisture extraction rate increased because it is inversely proportional.

Table 3 - Case 2: Cooling exchaust make-up air results

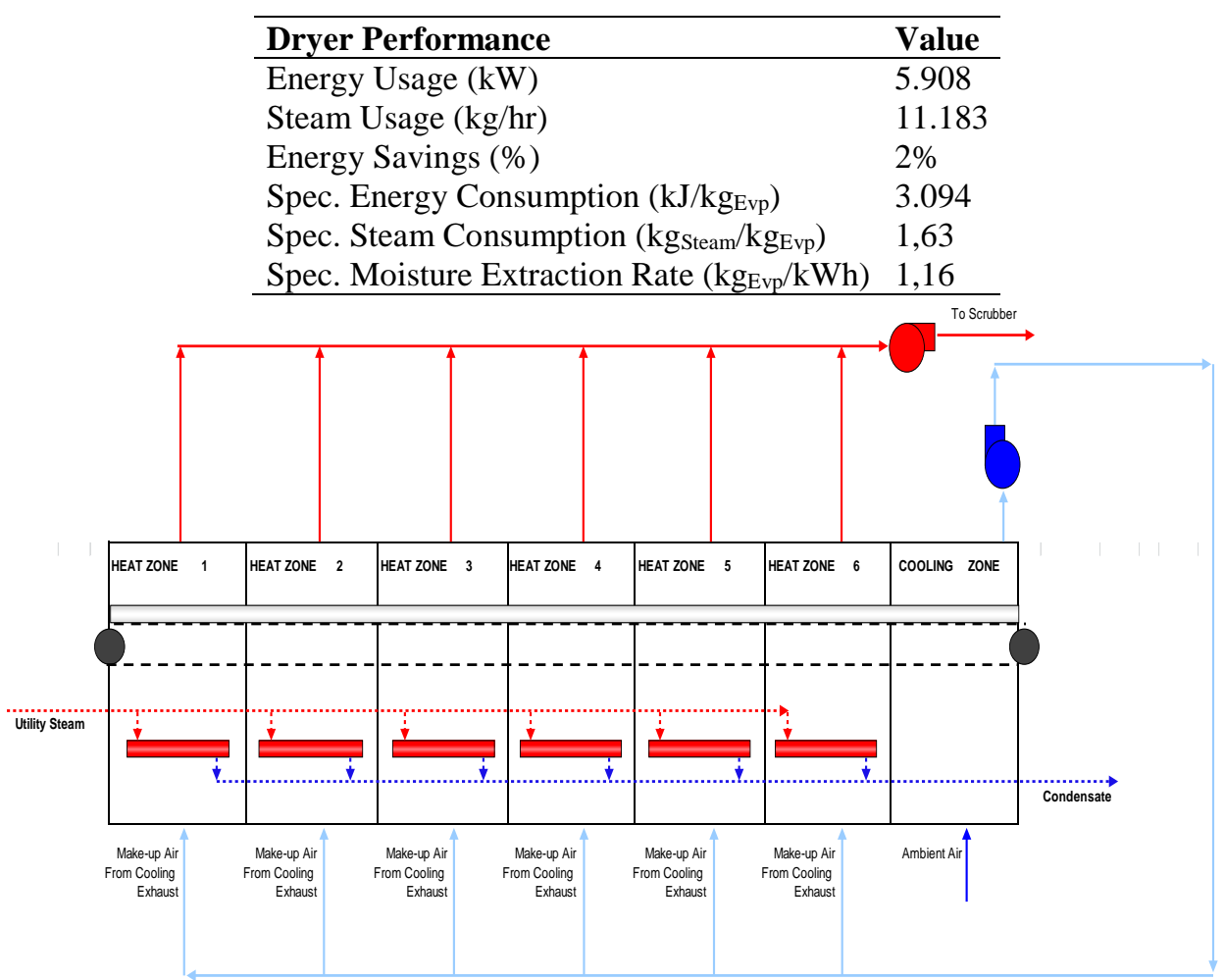

(BUHLER

Figure 5 - Case 2: Process flow diagram

\subsection{Cascading airflow}

Cascading airflow was simulated in Case 3. Similarly to Case 2, the cooling exhaust is utilized as make-up air; however, it only enters the dryer in heat zones 1, 2, and 6. The makeup air is introduced in zone 6 . The exhaust from zone 6 internally "cascades” as the make-up air to zone 5. This design is continued to zone 3 , where it is finally exhausted from the dryer. The cascading design conserves energy by reusing relatively dry preheated air.

Table 4 - Case 3: Cascading air flow results

\begin{tabular}{lc}
\hline Dryer Performance & Value \\
\hline Energy Usage $(\mathrm{kW})$ & 5.803 \\
\hline
\end{tabular}




\begin{tabular}{ll}
\hline Steam Usage $(\mathrm{kg} / \mathrm{hr})$ & 10.983 \\
Energy Savings (\%) & $4 \%$ \\
Spec. Energy Consumption $\left(\mathrm{kJ} / \mathrm{kg}_{\text {Evp }}\right)$ & 3.039 \\
Spec. Steam Consumption $\left(\mathrm{kg}\right.$ steam $\left./ \mathrm{kg}_{\text {Evp }}\right)$ & 1,60 \\
Spec. Moisture Extraction Rate $\left(\mathrm{kg}\right.$ Evp $\left._{\mathrm{kWh}}\right)$ & 1,18 \\
\hline
\end{tabular}

Depending upon the drying characteristics of the product and the configuration of the dryer, some applications permit cascading airflow through all the heat zones. A prime example of cascading airflow would be a rubber dryer. Consequently for gel drying, there is a high evaporation load in the first two heat zones in addition to the change in airflow direction from zones 2 to 3 . Therefore, it is mechanically and thermodynamically impractical to cascade airflow from zone 6 to zone 1 for gel drying applications.

Table 4 depicts the results of the energy analysis for cascading airflow. In comparison to Case 1 , there is a $4 \%$ reduction in energy consumption.

\subsection{Flash steam}

Table 5 - Case 4: Flash steam result

\begin{tabular}{ll}
\hline Dryer Performance & Value \\
\hline Energy Usage $(\mathrm{kW})$ & 5.456 \\
Steam Usage $(\mathrm{kg} / \mathrm{hr})$ & 10.328 \\
Energy Savings $(\%)$ & $10 \%$ \\
Spec. Energy Consumption $\left(\mathrm{kJ} / \mathrm{kg}_{\text {Evp }}\right)$ & 2.857 \\
Spec. Steam Consumption $\left(\mathrm{kg} \mathrm{kteam}_{\mathrm{kg}} / \mathrm{kg}_{\text {Ev }}\right)$ & 1,50 \\
Spec. Moisture Extraction Rate $\left(\mathrm{kg} g_{\text {Evp }} / \mathrm{kWh}\right)$ & 1,26 \\
\hline
\end{tabular}

Flash steam is generated when high pressure condensate, from the internal steam coils, is released to low pressure. The excess latent heat allows some of the condensate to reevaporate into steam (Spirax Sarco Inc., "Design of Fluid Systems - Steam Utilization" 2012). The design for the flash steam systems requires that the low pressure flash steam be a minimum of $520 \mathrm{kPa}$ below the high pressure condensate.

In the drying simulation, the low pressure flash steam is utilized via an external steam coil. The exhaust air from the cooling section is ducted to the low pressure steam coil. After the air is preheated by the flash steam, it is then distributed to each heat zone.

In the simulator, the condensate was leaving the dryer at $1765 \mathrm{kPa}$ and the flash tank was operating at $690 \mathrm{kPa}$. Based on the energy balance, the dryer produced condensate at a rate of 10,330 kg/hr. The flash steam system was able to recover nearly $500 \mathrm{~kW}$ of power from the high pressure condensate in the form of lower pressure steam. Table 5 lists the values from the flash steam energy balance. The flash steam modifications yielded energy savings of $10 \%$ when compared to the base case scenario. 


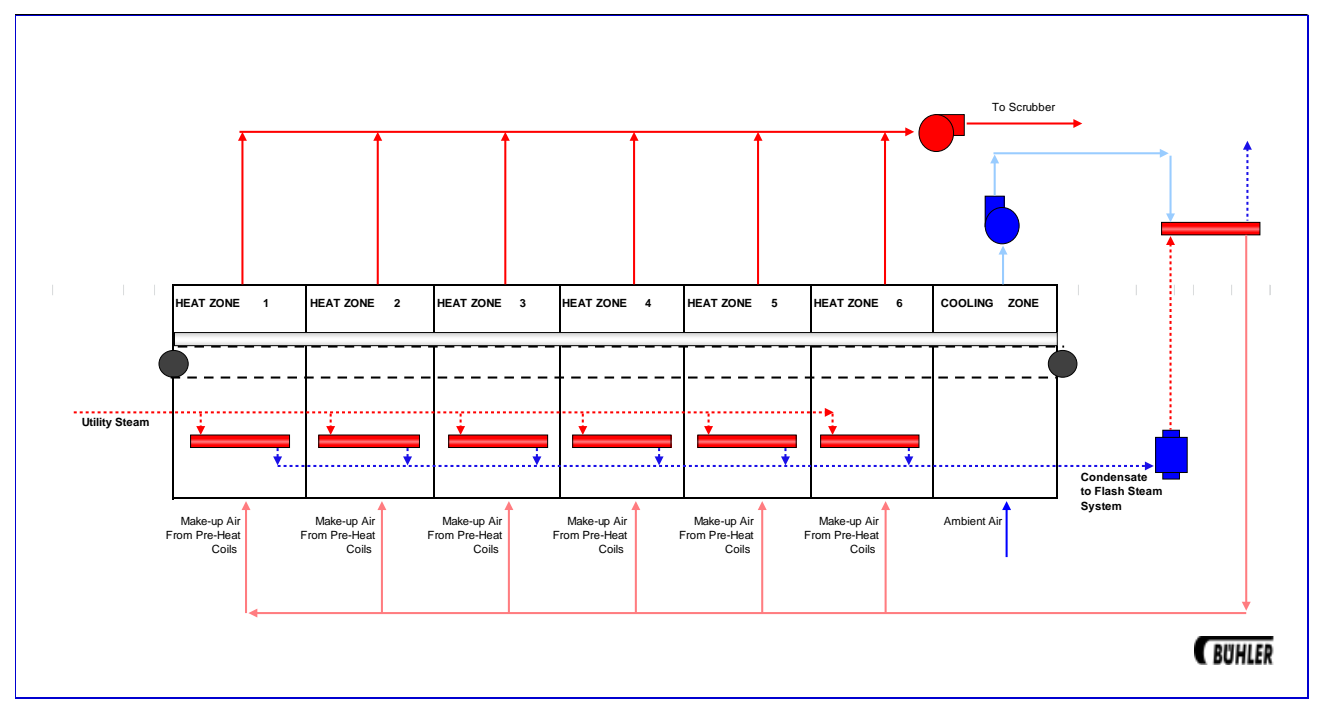

Figure 6 - Case 4: Process flow diagram

\subsection{Air-to-air heat exchanger}

The air-to-air heat exchanger recovers heat from the exhaust streams that would have otherwise been released to the environment. Once again, the make-up air is supplied from the cooling exhaust/transfer fan. An illustration of the dryer configuration can be seen Figure 8.

A counter-current parallel plate and frame heat exchanger is used to reduce pressure drop and achieve improved approach temperatures between the hot exhaust air and cooler make-up air. Pressure drop becomes a concern while sizing transfer and exhaust fans. Typically, the pressure drop across the heat exchanger is between 620-750 $\mathrm{Pa}$; thus, significantly increasing the fans' motor sizing. There are also design considerations in regards to the approach temperatures of the make-up air. For petroleum based gel polymers, the efficiency of the heat exchanger is limited by the formation of condensation in the exhaust stream. The humid exhaust air contains gel particulate, which will foul the heat exchanger if water condenses along the heat transfer surface area. Therefore, the exhaust temperature must maintain at least an $11^{\circ} \mathrm{C}$ buffer above the dew point temperature. $\left(\mathrm{T}_{\mathrm{EX}} \geq \mathrm{T}_{\mathrm{DEW}}+11^{\circ} \mathrm{C}\right)$. This exhaust temperature set point is used as a design parameter for the heat exchanger. 


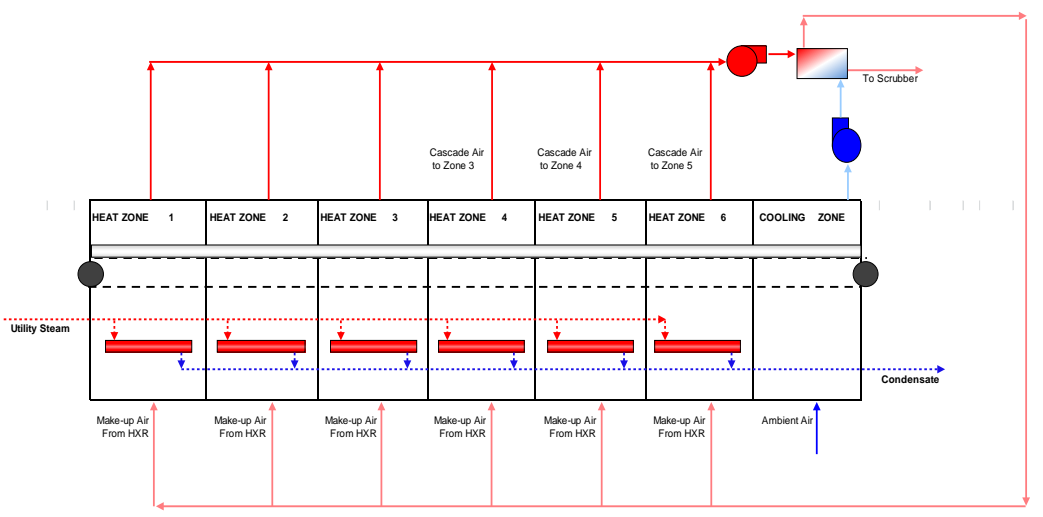

(BUHLER

Figure 7 - Case 5: Process flow diagram

Table 6 - Case 5: Heat exchanger results

\begin{tabular}{ll}
\hline Dryer Performance & Value \\
\hline Energy Usage $(\mathrm{kW})$ & 5.396 \\
Steam Usage $(\mathrm{kg} / \mathrm{hr})$ & 10.213 \\
Energy Savings $(\%)$ & $11 \%$ \\
Spec. Energy Consumption $\left(\mathrm{kJ} / \mathrm{kg}_{\text {Evp }}\right)$ & 2.826 \\
Spec. Steam Consumption $\left(\mathrm{kg}_{\text {Steam }} / \mathrm{kg}_{\text {Evp }}\right)$ & 1,49 \\
Spec. Moisture Extraction Rate $\left(\mathrm{kg}\right.$ Evp $\left._{\mathrm{kWh}}\right)$ & 1,27 \\
\hline
\end{tabular}

Despite these design considerations, counter-current air-to-air heat exchangers improve the energy efficiency of system. Table 6 shows the benefits of recovering energy from the exhaust air stream to preheat the make-up air. There were $11 \%$ energy savings; however, case studies show potential energy savings up to 16\% (Mujumdar A. "Handbook of Industrial Drying” CRC Press. November 2006).

\subsection{Combined energy conservation measures}

Table 7 - Case 6: Cambined energy conservation results

\begin{tabular}{ll}
\hline Dryer Performance & Value \\
\hline Energy Usage $(\mathrm{kW})$ & 4.917 \\
Steam Usage $(\mathrm{kg} / \mathrm{hr})$ & 9.306 \\
Energy Savings $(\%)$ & $19 \%$ \\
Spec. Energy Consumption $\left(\mathrm{kJ} / \mathrm{kg}_{\text {Evp }}\right)$ & 2.575 \\
Spec. Steam Consumption $\left(\mathrm{kg}\right.$ Steam $\left./ \mathrm{kg}_{\text {Evp }}\right)$ & 1,35 \\
Spec. Moisture Extraction Rate $\left(\mathrm{kg}_{\text {Evp }} / \mathrm{kWh}\right)$ & 1,40 \\
\hline
\end{tabular}

Case 6 combined the energy features described in Cases 2-5. First, the exhaust air from the cooling section was passed through an air-to-air heat exchanger. Hot exhaust air from zones 
1, 2, and 3 ran counter-current to the preheated make-up air. The second feature involved further heating the make-up air using flash steam coils. Then, the hot make-up air was ducted to zones 1, 2, and 6. Finally, the air was cascaded from zone 6 to 3, where it was exhausted from the dryer.

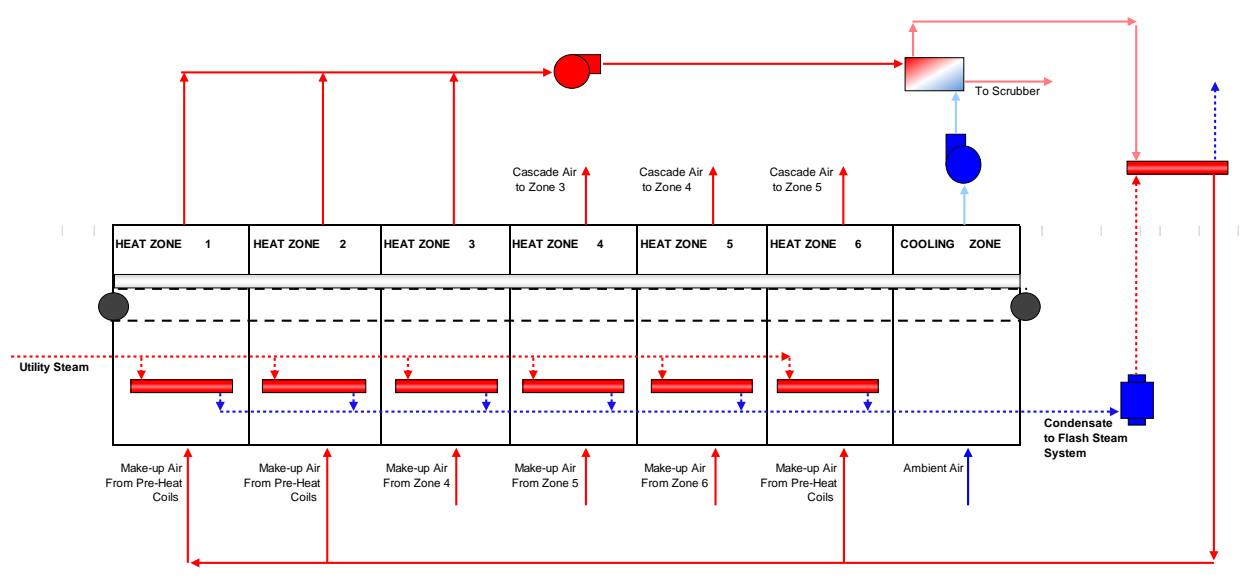

BUHLER

Figure 8 - Case 6: Process flow diagram

The combined energy savings from the heat recovery features was $19 \%$ when compared to Case 1. The specific steam consumption was determined to be $1.35 \mathrm{~kg}$ steam $/ \mathrm{kg}_{\text {Evp. }}$.

\subsection{Energy Savings Results}

The energy savings were calculated using a mass and energy balance at the design conditions. A nominal throughput of five tons per hour was selected as the production rate for the gel dryer. Operating parameters were consistent with the industry's standard. The theoretical savings are summarized in Table 8.

The heat recovery options were compared separately to the base case scenario, which had no energy saving features. Each energy case was not added incrementally to the same simulation. Since each energy saving option was evaluated and optimized independently, there are overlapping savings between each option. Therefore, the "Combined" savings are not cumulative and will not equal the sum of the individual options. 
Table 8 - Energy conservatioin measure results summary

\begin{tabular}{|c|c|c|c|c|c|c|}
\hline $\begin{array}{l}\text { Dryer } \\
\text { Production } \\
\text { Rate } \\
5000 \mathrm{~kg} / \mathrm{hr}\end{array}$ & $\begin{array}{l}\text { Steam } \\
\text { Usage } \\
(\mathrm{kg} / \mathrm{hr})\end{array}$ & $\begin{array}{c}\text { Energy } \\
\text { Usage } \\
(\mathrm{kW})\end{array}$ & $\begin{array}{c}\text { Spec. Steam } \\
\text { Consumption } \\
\text { (kgSteam/kgEvp) }\end{array}$ & $\begin{array}{c}\text { Spec. Energy } \\
\text { Consumption } \\
\text { (kJ/kgEvp) }\end{array}$ & $\begin{array}{c}\text { Spec. } \\
\text { Moisture } \\
\text { Extraction } \\
\text { Rate } \\
\text { (kgEvp/kWh) }\end{array}$ & $\begin{array}{c}\text { Energy } \\
\text { Saving } \\
\text { (\%) }\end{array}$ \\
\hline Base Case & 11.442 & 6.045 & 1,66 & 3.166 & 1,14 & - \\
\hline $\begin{array}{l}\text { Cooling } \\
\text { Exhaust } \\
\text { MUA }\end{array}$ & 11.183 & 5.908 & 1,63 & 3.094 & 1,16 & $2 \%$ \\
\hline Cascading & 10.983 & 5.803 & 1,60 & 3.039 & 1,18 & $4 \%$ \\
\hline $\begin{array}{l}\text { Flash } \\
\text { Steam }\end{array}$ & 10.328 & 5.456 & 1,50 & 2.857 & 1,26 & $10 \%$ \\
\hline $\begin{array}{l}\text { Heat } \\
\text { Exchanger }\end{array}$ & 10.213 & 5.396 & 1,49 & 2.826 & 1,27 & $11 \%$ \\
\hline Combined & 9.306 & 4.917 & 1,35 & 2.575 & 1,40 & $19 \%$ \\
\hline
\end{tabular}

\section{Product Quality Control}

During drying, the control of product quality attributes is critical to successful production. Parameters such as moisture content, color, and specifically for nut roasting the reduction in pathogens should be measured and controlled within the process. Methods for modelling and/or measuring these key product quality parameters will be discussed as well as how the dryer process parameters may be manipulated to maintain the values within the users' specifications.

\subsection{Increased dryer yield}

Even small percentage gains can mean significant increases in yield and profitability over time. A product moisture control will automate the dryer operation to optimize performance, bringing more product closer to target moisture. This increases overall yield by preventing over drying. It also eliminates the risks associated with under drying. Continuous monitoring, constant control uses suitable sensor technology for the specific product to be dried. Typically larger extruded products, the moisture content can be determined via their dielectric properties using microwave or capacitive sensors. While fine materials or surface drying applications near infrared based sensors are successful. These types of sensors coupled with controls that use algorithms built on decades of technical drying experience allow dryer manufacturers to provide benefits to their customers. The resulting 
comprehensive closed loop system delivers full time automated control of the dryer. The moisture content at the dryer's output is sampled continuously and the necessary adjustments to the dryer are made immediately, eliminating the need for manual sampling and the associated time gaps between sampling, testing, and making dryer adjustments. This fully automated method significantly increases the frequency of sampling and moves more of the product closer to the target moisture content. Consistent, reliable dryer management improves energy efficiency by making the correct dryer control decisions quickly and reliably. Moisture content targets can be input by operator or by recipe control, and the dryer will automatically establish and maintain the optimal drying environment for the remaining production run. This eliminates the wasted energy and product that can result from manually attempting to reach a moisture target.

\subsection{Ensuring safe thermally processed food.}

In the USA alone, the annual cost of foodborne outbreaks caused by harmful bacteria, is $\$ 17 \mathrm{~B}$ USD. Each recall can cost a single company up to \$30M USD per incident. The number of recalls have doubled over the last 10 years. As a consequence of these incidents, there are new legal requirements (FSMA - Food Safety Modernization Act) in the USA that put much more pressure on food manufacturers in the form of increased government oversight and greater customer scrutiny. One recall due to food safety failings can be disastrous to a company or a brand.

Beyond the financial considerations, there are far greater consequences from food safety incidents. The Centers for Disease Control and Prevention (CDC) estimates that each year roughly 1 in 6 Americans (or 48 million people) get sick, 128,000 are hospitalized, and 3,000 die of foodborne diseases. As part of the food supply chain, we all bear a moral obligation to ensure we are producing the safest food possible for consumption by the public.

\subsubsection{Regulatory requirements}

In 2011, the Food Safety Modernization Act became law. It is the most sweeping reform of US food safety laws in more than 70 years. With it came many new legal requirements for food processors. Among these new requirements is the need to guard against bacterial hazards in the food production process. Processors must now:

- Analyze potential hazards in the food being processed

- Put preventive controls in place

- Validate the process to show the controls work

- Record process data to show the controls are met

- Be able to recall data quickly upon request

For many foods where bacteria presence is known or expected, a kill step is the typical control. This step separates unsafe raw material from a safe-to-eat consumer product. The 
kill step is usually a high temperature process, meaning processors can use existing processes originally designed for operations such as roasting of nuts, as a kill step for bacteria. Gaining insights to a process to ensure that it is capable of delivering the required kill, and then monitoring and recording processing conditions, is currently done using tedious methods that are time consuming, costly, manual, and vulnerable to human errors and adulteration. Many times there are also conflicts between food safety and quality needs.

\subsubsection{Ensuring the Kill Step}

With enhanced processing monitoring, food manufacturers can now take full advantage of their dryer manufacturer's food safety expertise and food technology knowledge to meet these new challenges. A system that can provide a continuous real time view into the thermal process, enables operators to react faster to process changes, reducing product losses and increasing production time, while its digital data recording, storage, and reporting capabilities help to reduce the vulnerabilities associated with manual and paper-based methods.

\section{Sharing Success - A Partnership between Dryer Users and Dryer Manufacturers}

Having this process instrumentation and controls isolated at the plant level does not benefit the corporation as a whole. Utilizing the Industrial IoT and data analytics allows this information to be shared throughout the plant, multiple corporate facilities and the process equipment vendor. Some of the benefits of this partnership are listed below.

1. It will be possible for the drying process to be monitored in real-time from any location. This will allow the management to respond to unexpected upsets, eliminate wasted idle time, and reduce inventory ready to ship to customers. Data from multiple sites will allow comparison of plant efficiencies and methodologies to improve each production line.

2. Connected dryers can be monitored and managed remotely. The dryer operator does not need to directly in front of a control panel in order to adjust the process. Smart sensors and algorithms can be used to better understand what is happening within the drying process which can improve the final product, conserve energy costs and improve overall profitability.

3. The dryer information from multiple sites can be monitored and modelled to form a predictive maintenance algorithm. This will allow dryer operators to reduce downtime and achieve a greater return on their capital investment.

4. Information may be used to study cause and effects that may result in material not meeting specifications. Data affecting quality can be sent to the right people in real time so that they may make informed decisions and work to identify problems, find the root cause and implement solutions. This data can then be used to confirm the solution.

5. This information can help the management team make decisions in a competitive environment in real time by seeing what is happening on their plant floors throughout 
the company. This will allow them to better manage overall operating costs and efficiencies.

\section{Conclusions}

A partnership between an equipment supplier and the user of the equipment can have many benefits as described above that can lead to the optimal use of energy (minimize energy input into the drying step) to lower operating costs. Communications and data sharing through the Internet of Things will allow the partnership to succeed through multiple plant locations to result in the optimal use of resources, plant process lines and increased production quality. 